\title{
KEPERCAYAAN BAGAMPIRAN ANTARA MANUSIA DENGAN MAKHLUK GAIB DI AMUNTAI
}

\author{
Arni \\ Dosen Jurusan Perbandingan Agama Fakultas Ushuluddin IAIN Antasari, J1. A. \\ Yani Km. 4.5 Banjarmasin Hp 085249361200
}

Diterima 17 Nopember 2009/ Disetujui 15 Desember 2009

\begin{abstract}
Some Banjarese living in Amuntai believe that when a baby is born, sometimes he or she is accompanied by another unseen baby. In other words, the baby is twin, one is seen, while another is unseen. The latter will appear to a certain people of his/her family. The unseen person could be good or bad to them. It is believed that if the family regularly feed the unseen person with special traditional cakes, bitter and sweet coffee, he or she will be good to the family.
\end{abstract}

Kata kunci: Orang Banjar, bagampiran, familier, supernatural.

\section{Pendahuluan}

Orang Banjar adalah nama untuk penduduk yang mendiami daerah Kalimantan Selatan, dan etnik ini telah menyebar ke berbagai daerah. Orang Banjar ini setidak-tidaknya terdiri dari etnik Melayu sebagai etnik yang dominan kemudian bercampur dengan suku Dayak Bukit, Ngaju dan Maanyan. Islam sudah merupakan identitas atau ciri mereka, sehingga seseorang, dari kalangan Dayak di daerah ini yang beralih keagama Islam, sering disebut menjadi orang Banjar. ${ }^{1}$

Masyarakat Banjar menganut agama Islam, akan tetapi kepercayaan mereka masih bercampur dengan kepercayaan primitif. Seperti yang dijelaskan oleh Alfani Daud bahwa suku Banjar yang tinggal di daerah ini sebagian mereka masih mempercayai tokoh-tokoh di dalam silsilah

${ }^{1}$ Tim, Sejarah Banjar, (Banjarmasin: Badan Peneliti dan Pengembangan Daerah Kalsel, 2004), h. 1. 
raja-raja Banjar masih hidup di alam gaib sampai sekarang, yang bertempat di gunung Candi, gunung Pamaton, gunung Batu Gampar, di Muara Cerucuk, di tempat pemukiman penduduk dll. Tempat yang angker di sekitar perkampungan juga terkadang dianggap sebagai pemukiman orang gaib. Berbagai istilah untuk menyebutkan gangguan orang gaib ini terhadap manusia yakni kapubunan, kataguran, kapingitan, kasurupan dan kasarungan. ${ }^{2}$

Dalam kehidupan masyarakat Banjar, banyak masalah dan fenomena menarik yang layak untuk ditelusuri. Salah satu fenomena tersebut adalah berkenaan dengan hubungan kekerabatan antara manusia dengan orang gaib yang sering disebut dengan istilah "bagampiran”. Orang gaib ini adalah orang yang telah digaibkan Allah baik ketika masih dalam kandungan atau setelah lahir dan telah besar. Bagi masyarakat Banjar istilah bagampiran dengan orang gaib adalah sesuatu yang tidak asing, dan kepercayaan ini telah diyakini oleh sebagian besar masyarakat di daerah ini. Umumnya bagampiran terjadi kerena ada hubungan darah (keturunan). Kalau orang gaib menghendaki untuk bagampir kepada seseorang, disadari atau tidak, dikehendaki atau terpaksa maka akan terjadi.

Menurut bahasa Banjar, bagampiran berasal dari kata gampir, mendapat awalan ba dan akhiran an, maknanya menjadi satu secara bersama-sama (dempet). Dengan demikian bagampiran bisa bermakna kembar dan menjadi satu. Namun, gampir dimaksud, dalam bahasa Banjar bukan berarti bersatu secara fisik, melainkan secara non fisik dan tidak berada dalam alam nyata, yang satu hidup di alam nyata dan yang satunya di alam gaib (metafisik). Bagampiran bisa terjadi antara seseorang dengan saudara kembar yang gaib, dan bisa dengan tokohtokoh tertentu yang menjadi orang gaib, bisa juga dengan jin, dan lainlain, sebagaimana yang akan diuraikan dalam kasus-kasus yang ditemui di masyarakat.

Bagampiran adalah sesuatu yang bersifat positif dan juga bisa negatif. Sifat dari barasuk dalam rangka untuk menolong orang lain adalah sesuatu yang positif, sedangkan sifat dari kesurupan adalah pasif negatif. Jika barasuk dan kesurupan bersifat sementara, maka begampiran lebih permanen. Karena

${ }^{2}$ Alfani Daud, Islam dan Masyarakat Banjar (Jakarta: PT. Raja Grafindo Persada 1997), h. 406. 
itu bagampiran berbeda dengan kesurupan, sebab walaupun orang yang digampiri atau dirasuki sama-sama tidak sadar, namun pada kesumpan lebih membawa mudharat kepada orang yang dirasuki. Sedangkan orang yang dimasuki oleh gampirannya maka lebih bersifat menolong terhadap orang yang digampiri. Bahkan waktu-waktu terjadinya bagampiran itu adalah waktuwaktu yang biasanya memang diperlukan, misalnya karena ada orang meminta pertolongan dan hajat tertentu atau karena ada sesuatu yang bersifat penting yang hendak diberitahukan oleh gampirannya, atau karena gampirannya sedang dalam bahaya, dan lain-lain.

Dilihat dari pengertian di atas, maka secara maknawi, bagampiran juga memiliki dan memperlihatkan kesamaan arti (sifat) dengan reinkarnasi yang dipercayai oleh orang-orang Tionghoa dan pengikut Dalai Lama di Tibet. Konsep bagampiran juga mengingatkan kita dengan proses Ittihbad atau hulûl (penyatuan dengan Tuhan) dalam dunia sufi.

Dalam realitas masyarakat Banjar sendiri bagampiran adalah sesuatu yang bersifat personal dan magis, diakui dan dipercayai oleh masyarakat luas, karena dialami oleh orang-orang tertentu. Walaupun secara rasional ilmiah agak sulit dibuktikan, namun bagampiran sebagai fenomena metafisik merupakan sesuatu yang khas berkenaan dengan faham dan kepercayaan masyarakat Banjar.

Berdasarkan penjelasan di atas, bagampiran cukup signifikan untuk diteliti, karena secara luas memperlihatkan berbagai permasalahan penting kepada kita berkenaan dengan kepercayaan orang Banjar terhadap dunia gaib. Misalnya, Apakah yang menggampiri tersebut berupa roh atau jin? Apakah benar manusia biasa (tokoh-tokoh tertentu) bisa berubah, tidak mati, dan menjadi penghuni alam gaib, sehingga bisa dihubungi? Apakah seseorang bisa pindah statusnya, dari penghuni alam dunia menjadi penghuni alam gaib? dan seterusnya.

Pertanyaan-pertanyaan tersebut mungkin terasa berat dijawab oleh pelaku bagampiran, atau paling tidak penelitian ini dapat mengungkap faktafakta di masyarakat seputar bagampiran. Persoalannya bagaimana proses dan pengalaman dalam bagampiran serta kepercayaan dan aktivitas keagamaan yang berhubungan dengan bagampiran tersebut? Semua data yang didapat diharap dapat mendeskripsikan segala persoalan yang berhubungan dengan bagampiran 
Penelitian ini termasuk dalam kategori penelitian lapangan, yang bersifat studi kasus. Objeknya proses bagampiran, pengalaman-pengalaman yang dirasakan, kepercayaan dan aktivitas keagamaan dalam menghadapi makhluk gaib tersebut. Sedangan Subjeknya adalah mereka yang bagampiran di daerah Amuntai yang dianggap dapat mewakili daerah-daerah lainnya di Kalsel. Mereka itu ialah, Fatmah, Hj. Sawiyah, Suriani, dan Isnaniyah. Semua data dihimpun dari mereka melalu wawancara mendalam.

\section{Pembahasan}

Kasus-kasus familier antara manusia dengan makhluk gaib (supernatural) dengan istilah bagampiran, ternyata ditemui di beberapa daerah di Kalimantan Selatan, sebagai contoh di Amuntai.

Berikut ini dilaporkan secara deskriptif masalah adanya hubungan familier antara manusia dengan makhluk gaib atau bagampiran ini, sesuai dengan fakta-fakta yang terjadi di kalangan masyarakat Banjar maupun pandangan dan kepercayaan masyarakatnya berkenaan dengan masalah bagampiran, yaitu:

\section{Kasus I (Hj. Fatmah)}

Pada dasarnya di kalangan masyarakat Banjar pengalaman bagampiran ini disebabkan adanya hubungan darah yang dimulai dari peristiwa kelahiran. Ada beberapa kasus bagampiran yang sebabnya memang berasal dari hubungan darah dan dimulai dari peristiwa kelahiran. Sebagai contoh ialah yang terjadi pada Fatmah (perempuan, 70 tahun) yang beralamat di desa Kotaraja RT. IV Kecamatan Amuntai Selatan, dia mempunyai anak sebanyak enam orang. Peristiwa bagampiran terjadi pada anaknya yang paling bungsu (perempuan), yang berinisial In. Sewaktu melahirkan ternyata ada dua kaladut ${ }^{3}$ dan dua tali pusar. Kaladut yang satu tidak ada bayinya, tetapi masih ada tali pusarnya. Orang yang hadir ketika peristiwa kelahiran itu yakin bahwa bayi yang lahir adalah kembar, tetapi yang satunya menghilang. Fatmah menuturkan dia

${ }^{3}$ Kaladut (dalam bahasa Banjar) adalah semacam kulit pembungkus bayi sejak dalam kandungan. 
merasa ada dua bayi yang keluar secara bergantian saat melahirkan. Dan masyarakat mempercayai kaladut orang bagampiran dapat dijadikan jimat untuk kekebalan.

Dia mengetahui secara pasti bayi yang hilang ketika dilahirkan tersebut adalah gampiran dari anaknya yang lahir, hal ini karena diberitahu oleh bidan beranak. Gampiran dari anaknya yang berinisial In tersebut adalah berjenis kelamin laki-laki.

Makhluk gaib yang merupakan gampiran ini terkadang bisa menampakan diri, dan dapat menggampiri siapa saja dari keluarganya, yang ada hubungan familier. Umpamanya saudari yang tertua yang berinisial Irs pernah melihat di bawah tempat tidur (ranjang) ada makhluk gaib yang berbentuk manusia tanpa kepala. Tetapi anak Irs melihat makhluk gaib itu secara sempurna, yaitu melihat bentuk lakilaki tampan yang berwajah sempurna. Dalam peristiwa lainnya ibunya(Fatmah) juga pernah menyaksikan makhluk gaib yang dianggapnya anaknya yang hilang ketika dilahirkannya dulu berbentuk seperti anak kecil berkepala gundul sambil memegang beras yang ada dalam tempayan (padaringan)

Begitu juga pengalaman lainnya, keluarga Fatmah ini ada mempunyai benda pusaka berupa parang mandau hasil peninggalan orang tuanya. Suatu ketika anak yang dianggap gaib menampakkan wujudnya ditangkai mandau tersebut berupa gambar kepala yang hidup atau bergerak dengan wujud perwajahan yang sangat tampan. Menyaksikan peristiwa ini keluarga Fatmah sangat yakin bahwa makhluk yang ada ditangkai mandau tersebut adalah gampiran atau anaknya yang dulu pernah hilang.

Keluarga Fatmah ini termasuk orang yang sederhana. Tn adalah adiknya, yang terpaksa menggadaikan benda pusaka berupa mandau sebesar lima belas ribu rupiah karena persoalan ekonomi. Akan tetapi sejak itu anaknya Fatmah yang berinisial Udn selalu mengalami sakit kepala yang tidak kunjung sembuh walaupun sudah berobat secara medis, baik ke puskesmas ataupun dokter spesialis. Namun ketika diperiksa kepada seorang paranormal yang berinisial Ai di Amuntai selatan, yang dari hasil pemeriksaannya secara batin memberikan petunjuk bahwa ada benda 
pusaka yang tidak dipelihara. Padahal benda pusaka tersebut adalah tempat bersemayamnya makhluk gaib gampiran.

Setelah mendapat petunjuk dari paranormal tadi secepatnya Udn menebus benda pusaka dimaksud untuk kembali dipeliharanya. Anehnya setelah itu dilakukan, secara tiba-tiba rasa sakit kepala yang setiap hari dideritanya hilang seketika. Menurut tabib Ai, benda pusaka berupa mandau tersebut harus dipelihara karena akan mendatangkan rezeki dan hidupnya akan berkecukupan. Karenanya hingga kini mandau tersebut dipelihara dengan cara dibersihkan tiap bulan, karena kalau tidak dibersihkan maka mandau tersebut akan bergerak dengan sendirinya. Dengan memelihara benda pusaka ini menurut Fatmah terbukti keluarganya hidup dengan berkecukupan.

Makhluk gaib yang diyakini sebagai keluarga gampiran ini meminta perhatian antara lain dengan cara mengganggu keluarganya. Hal ini dialami oleh cucu Fatmah yang berinisial Ptr (anak Irs) yang terganggu pendengarannya, Ptr ini oleh keluarganya dipercayai adalah keturunan orang candi (tutus candi Agung). Oleh karena itu keluarga Fatmah menjalin hubungan dengan anak gaib (gampiran) dengan cara memberikan sajen setiap malam Senin berupa: nasi kuning, kopi pahit dan manis, tapai, pisang talas, cengkaruk dan wajik. Sajen ini diletakkan di atas meja di dalam kamar kosong dengan harapan tidak menggangu keluarga. Pada mulanya sajen dipersembahkan setiap malam Jum'at, tetapi setelah diketahui makhluk gampiran adalah tutus candi maka sajen dilaksanakan setiap malam Senin. ${ }^{4}$

\section{Kasus II (Hj. Sawiyah)}

Hj. Sawiyah (82 tahun, Kotaraja Amuntai) memiliki tiga orang saudara (satu orang saudara seibu sebapa dan dua orang saudara sebapa). Ayah mereka yang bernama H. Isa bin H. Sontong (Almarhum) memiliki saudara gaib (gampiran) yang ketika berumur dua hari telah menghilang. Saudara gaib ini bernama Kesumagiri yang bertempat tinggal di Aceh. Keluarga Kesumagiri ini selalu berkunjung kepada istri $\mathrm{H}$. Isa, yaitu $\mathrm{Hj}$. Ramlah atau ibu dari $\mathrm{Hj}$. Sawiyah. Dalam kunjungannya Kesumagiri dan

${ }^{4}$ Wawancara Pribadi dengan Hj. Fatmah di Amuntai pada tanggal 02 -09-2007. 
keluarganya berwujud manusia biasa, sehingga mereka mudah berkomunikasi, bercanda dan sebagainya. Tetapi manakala dia pamit melangkah kaki untuk pulang, disaat itulah dalam waktu sekejap mereka menghilang. Peristiwa kunjungan kekeluargaan ini terjadi berulang-ulang sehingga dianggap peristiwa biasa saja. Setelah H. Isa meninggal dunia Kesumagiri tidak pernah lagi datang berkunjung membawa keluarganya yang menampilkan diri seperti manusia.

Kesumagiri (gampiran gaib) ini sempat bagampir dengan anak $\mathrm{Hj}$. Sawiyah yang bernama $\mathrm{Hj}$. Khadijah sehingga $\mathrm{Hj}$. Khadijah bisa menolong orang yang sakit atau menemukan barang yang hilang. Namun Hj. Ramlah (ibu $\mathrm{Hj}$. Sawiyah) merasa keberatan kalau cucunya menjadi seorang tabib (penambaan), sehingga hubungan dengan saudara gaib diputuskan atau ditalak. Sejak saat itulah Hj.Khadijah tidak memiliki keahlian dalam hal menyembuhkan atau menemukan barang hilang. Dengan diputusnya hubungan gampiran tidak menimbulkan akibat negatif, malah sebaliknya ada bantuan positif yang dialami oleh anak $\mathrm{Hj}$. Khadijah yang bernama Hj. Raudhah. Hj. Raudhah mengakui saudara gampiran gaib datuknya yang bernama Kesumagiri datang membantunya disaat hendak menjalani operasi untuk kelahiran bayi kembarnya. Menurut pengakuan $\mathrm{Hj}$. Raudhah, Kesumagiri itu datang dalam wujud manusia yang berpakaian serba hijau sebagaimana layaknya seorang pangeran, dan berkata kepada $\mathrm{Hj}$. Raudhah "aku datang membantu keluarga keturunan atau zuriatku yang sedang dalam kesulitan”. Bentuk pertolongan yang diberikan Kesumagiri tidak diketahui namun Hj. Raudhah selamat dalam melahirkan anak kembarnya. Adapun yang menjadi penyebab dibawa ke rumah sakit untuk dioperasi karena seorang bayinya meninggal dalam kandungan, sehingga sulit melahirkan.

Walaupun keluarga Hj. Raudhah (cucu Hj. Sawiyah) ini mengetahui adanya keluarga gampiran yang berada di alam gaib, namun karena mereka berpengetahuan agama sehingga tidak memberikan sajen kepada makhluk gaib tersebut.

Terkadang cucu Hj. Sawiyah melihat seorang lelaki berpakaian putih, pakai peci yang duduk di kursi tamu. Setelah diperhatikan orang tersebut kemudian menghilang. ${ }^{5}$ 


\section{Kasus III (Suriani)}

Peristiwa lainnya dialami oleh keluarga Suriani (48 tahun) yang beralamat di Desa Pelampitan Hilir Amuntai Tengah. Dia mempunyai anak perempuan yang bernama SM (7 tahun) yang lahir dalam keadaan cacat, yaitu mirip orang busung lapar dan tidak mempunyai anus. Anaknya yang bernama SM adalah anak kedua dari lima bersaudara. SM inilah yang diyakini oleh keluarga Suriani mempunyai saudara gaib (gampiran). Menurut Suriani anaknya itu sering digangngu oleh saudara kembarnya, sehingga selalu menangis pada malam hari. Sewaktu isteri Suriani mengandung SM sering bermimpi bertemu dengan habib Basirih. Sementara ketika melahirkan ada tanda-tanda bayi kembar berupa dua kalubut, tambuni, dan sebagainya, yang ternyata bayinya cuma satu. Dalam kasus ini hilangnya bayi gampiran di dalam perut dan baru ketahuan setelah bertanya dengan orang pintar, yakni seorang perempuan tua sebagai paranormal, di Desa Muara Tapus. Menurut paranormal tadi anak Suriani yang bernama SM memiliki gampiran (kembaran) saudari laki-laki yang mulai bayi dalam perut telah diambil dan dipelihara oleh Usman Jaya (orang gaib) dari tutus candi Agung Amuntai. Anak gampirain itu telah diberi nama oleh Usman Jaya dengan nama Darma Kesuma. Penuturan paranormal ini setelah dia dirasuki oleh saudara gaib SM (Darma Kesuma). Dalam keadaan tidak sadar paranormal berbicara atas nama Darma Kesuma, agar dia diakui sebagai anak dan minta buatkan tempat tidur yaitu kelambu kuning yang selengkapnya (sebuah ranjang kecil yang bertutup kain kuning yang di dalamnya ada bantal guling). Permohonan itu telah disetujui oleh keluarga Suriani, sehingga pada kamar khusus tersedia kelambu kuning yang selengkapnya, serta diberi sajen pada malam Jum'at, berupa kopi pahit dan kopi manis, serta kue-kue dengan harapan anak yang gaib tidak mengganggu saudaranya yang cacat (SM).

Isteri Suriani selaku ibu kandung dari anaknya yang bagampiran tersebut secara fisik belum pernah bertemu anak kembarnya yang gaib. Namun sering bertemu dalam mimpi, yaitu berupa perempuan berambut panjang. Dalam mimpi tersebut saudara gampiran di alam gaib tersebut memberikan janji akan datang apabila di panggil. Pada suatu hari yang 
bersangkutan pernah memanggil dan ia datang, walaupun wujud fisiknya tidak terlihat dan hanya menunjukan tanda-tanda seperti benda di sekitar yang bergerak atau bunyi-bunyi seperti ada orang berjalan.

Pengalaman lainnya adalah ketika SM berumur antara tiga sampai tujuh hari, tempat tambuni dalam pot (kapit) yang di tanam di halaman rumah sering kedengaran bunyi seperti orang mencuci pakaian padahal kalau di perhatikan tidak ada orangnya. Kejadian seperti ini hampir terjadi setiap malam sampai ketika bayi SM berumur tujuh hari.

Suriani mempunyai dua orang isteri. Menurutnya, Isteri keduanya yang tinggal di Barabai, juga mempunyai gampiran yang bernama Hasim Sani Balkiah. Gampiran ini bukan dari saudara gaib, tetapi saudara gampiran datuknya yang sudah lama meninggal dunia. Gampiran ini dapat di panggil setiap saat apabila di perlukan.

Pengalaman bagampiran istri mudanya sebagaimana diceritakan Suriani adalah ketika ia kehilangsn cincin. Cincin tersebut tidak diketahui di mana hilangnya, setelah peristiwa itu diceritakan kepada isteri mudanya, maka isterinya memanggil sahabat gampiran untuk minta petunjuk. Tidak lama kemudian terdengar bunyi benda yang jatuh menimpa atap rumahnya, setelah dicari ternyata di atas atap ada cincin yang telah hilang tersebut.

Suriani sendiri mengakui bahwa kakeknya (padatuan) juga memiliki gampiran yang berbentuk ular, dari anaknya yang hilang. Gampiran berbentuk ular ini sering datang dalam wujud manusia. Dia datang menggampiri (merasuk ke dalam tubuh) siapa saja dari kalangan keluarga yang di sukainya, seperti ibu, bapa, saudara dan cucu-cucunya. Sehingga yang dirasukinya itu sebagai mana layaknya orang kesurupan. Namun berbeda dengan orang yang kesurupan pada umumnya, yaitu kesurupan karena bagampiran ini memberikan manfaat dan dapat dimintai bantuannya, seperti mengobati orang sakit, menemukan barang yang hilang, dan lain-lain

Suriani pernah mengeluh kondisi fisiknya yang tidak sehat disebabkan penyakit kencing manis. Orang yang menderita penyakit ini dapat mempengaruhi daya seks seorang suami terhadap isterinya, dan malah bisa menyebabkan impotensi. Keluhan ini dapat teratasi karena diberitahu orang gaib, (gampiran isteri mudanya), yang memberi tahu akar pohon tertentu 
sebagai obatnya. Setelah direndam akar pohon itu dalam air kemudian diminum ternyata terbukti khasiatnya. ${ }^{6}$

\section{Kasus IV (Isnaniyah)}

Isnaniyah berusia 40 tahun di Paliwara Amuntai, punya pengalaman tersendiri mengenai bagampiran. Dia mengatakan selama hidupnya pernah empat kali mengalami kehamilan. Namun pada hamil pertama, ketiga dan keempat mengalami keguguran. Sedangkan pada kehamilan kedua, anak yang dalam kandungan selalu berubah-ubah posisi, terkadang kepala di atas dan terkadang kepalanya ke bawah. Dan wujud badan bayi terkadang ada terkadang menghilang sendirinya. Isnaniyah menuturkan bahwa bidan (tukang urut) merasa ada kelainan sehingga merasa takut dan berpesan kepada Isnaniyah agar jangan dilibatkan bila dia mau melahirkan nanti.

Pada suatu malam ketika usia kandungan sembilan bulan, Isnaniyah bermimpi melahirkan anak di atas kain kuning. yang proses kelahirannya dibantu oleh paman (mamarina) suaminya yang gaib. Dan setelah dia bangun dari tidur ternyata perutnya mengecil (kempes). Memang banyak pengalaman aneh dirasakan ketika mengandung anak tersebut, misalnya senang dengan bunga yang diletakan di atas ranjang, badan selalu sehat sementara suami selalu sakit. Dia mengakui saat mengandung anak kedua itu, suaminya yang mengidam (kidam laki). Anak yang gaib itu diberinya nama Siti Qadariyah. Dia selalu dapat merasakan kehadiran anak yang gaib itu, di saat antara jaga dan tidur merasa ada anak yang menyusu kepadanya, dan ternyata di saat sadarnya air susunya selalu mengalir. Isnaniyah mengaku anaknya yang hilang dalam kandungan itu yang menyusu dan dianggapnya sebagai gampirannya.

Siti Qadariyah (anak yang gaib) selalu berkomunikasi kepada ayahnya melalui perantaraan ibunya (Isnaniyah). Dia merasuk meminjam jasad ibunya dan berkomunikasi dengan ayahnya, sebagaimana layaknya seorang anak yang berkomunikasi kepada orang tuanya. Hal ini selalu terjadi sampai sekarang kapan dan di manapun kalau diperlukan. 
Isnaniyah karena tidak mempunyai anak dalam wujud fisik, sehingga mengadopsi seorang anak laki-laki. Anak laki-laki ini dapat berkomunikasi dengan Siti Qadariyah melalui jasad ibunya. Dia bercanda, bermain, setiap harinya sebagaimana layaknya anak kecil bermain. Siti Qadariyah ini selalu membantu kedua orang tuanya. Bentuk bantuan ini misalnya katika orang tuanya tidak mempunyai uang untuk membuat Surat Tanda Nomor Kendaraan (STNK), kemudian Siti Qadariyah memberikan uang sebesar biaya yang diperlukan dalam pembuatan STNK tersebut.

Pengalaman lainya ketika kedua orang tuanya berkendaraan menuju ke tempat perkawinan keluarga di desa Hambuku, sewaktu dalam perjalanan ternyata menemui kendala, yaitu jalannya terputus disebabkan oleh arus banjir. Semua orang yang melewati jalan putus tersebut menggunakan perahu (jukung). Ketika kedua orang tuanya berpikir untuk membatalkan niatnya menghadiri upacara perkawinan itu, kemudian anaknya yang gaib membisikan di telinganya agar kedua orang tuanya meneruskan perjalanan dengan tidak melihat ke kiri ataupun ke kanan. Isnaniyah dan suaminya percaya dengan bisikan tersebut dan ternyata mereka dapat melewati jalan putus itu tanpa basah. Dia dapat berkendaraan di atas air melalui bantuan anaknya yang gaib tersebut.

Peristiwa lainnya Isnaniyah pernah bersepeda ke daerah Tanjung membawa barang dagangannya. Karena kelelahan dan tidak mampu lagi mengendarai sepedanya, namun anehnya sepeda yang dikendarainya berjalan dengan sendirinya sepanjang jalan yang dilewatinya hingga sampai ketujuannya.

Kejadian lainnya kedua orang tuanya pernah dibawa anaknya yang gaib ke alam gaib, sehingga dia dapat menyaksikan keindahan di alam gaib tersebut. Dia menyaksikan banyak gedung, jalan, dan tamantaman yang indah. Dalam pengakuan Isnaniyah, keadaan di alam gaib sebagaimana layaknya di alam nyata.

Peristiwa lain adalah ketika Isnaniyah dibantu oleh anak gaibnya dalam hal mengobati orang sakit maupun menemukan barang yang hilang. Sehingga banyak orang yang datang minta tolong sesuai keperluan. Namun apabila orang yang datang tidak melaksanakan shalat maka orang tersebut dimarahi dan tidak dilayaninya. Di antara sekian banyak orang yang datang kepada Isnaniyah ternyata banyak 
juga yang menanyakan masalah nomor judi (porkas). Sehingga sang anak menjadi marah dan tidak mau lagi memberi bantuan untuk orang lain yang datang kepada ibunya. Sejak saat itulah Isnaniyah tidak lagi mau memberi pelayanan kepada orang lain yang datang untuk meminta bantuan kepadanya. Kendatipun demikian Siti Qadariyah sewaktu-waktu tetap merasuk (menggampiri) ibunya. Siti Qadariyah dalam menggampiri ibunya malah mengajarkan bacaan ketika akan memakai pakaian, ketika memasang lengan baju harus mendahulukan yang sebelah kanan dengan membaca: Asybadu an lâ Ilaaha Illallâh, dan ketika memasang lengan baju sebelah kiri dengan membaca : Wa asyhadu anna Mubammadan Rasulullâb”. Dia juga mengajari orang tuanya ilmu Tajwid bagaimana cara membaca Alquran yang benar.

Untuk menciptakan hubungan yang harmonis dengan anaknya yang gaib tersebut, Isnaniyah memberikan sajen berupa air putih, pisang talas, telur ayam, dan nasi ketan setiap malam Senin. Sajen itu diletakkan di dalam kamar khusus. Pada awalnya ada disediakan tempat tidur kecil (kelambu kuning), namun setelah rumah Isnaniyah ikut terbakar kira-kira sepuluh tahun yang lalu, sejak itulah tidak lagi dibuatkan kelambu kuning.

Siti Qadariyah menggampiri ibunya (Isnaniyah) untuk menjadi perantara komunikasi dengan ayah atau adik angkatnya. Peristiwa ini terjadi hingga sekarang. ${ }^{7}$

\section{Analisis}

Dari berbagai kasus yang telah dilaporkan, ternyata para pelaku bagampiran mempunyai peristiwa atau pengalaman yang berbeda-beda, dan memberikan indikasi bahwa peristiwa bagampiran merupakan bagian dari kehidupan mereka.

Dari berbagai kasus yang telah ditemukan mengenai asal usul pengalaman bagampiran, sebagian besar berasal dari peristiwa kelahiran, yang anak bayinya hilang, baik dalam perut maupun hilangnya saat melahirkan, dan yang terasa hanya ada tanda-tanda adanya bekas bayi yang

${ }^{7}$ Wawancara Pribadi dengan Isnaniyah di Amuntai pada tanggal 09-09-2007. 
lahir (kasus I ,III, IV). Ada juga ketika dilahirkan, bayinya telah ada dan berwujud seperti bayi pada umumnya, namun beberapa hari kemudian menghilang (kasus II). Mereka yang mengalami peristiwa bagampiran, menyatakan bahwa gampiran (sahabat makhluk gaib), adalah berasal dari hubungan darah atau adanya hubungan keluarga. Gampiran tersebut bisa menggampiri saudaranya, orang tuanya, dan anak cucunya. Masyarakat Banjar menganggap bahwa gampiran (sahabat makhluk gaib) tersebut bukan jin ataupun malaikat, melainkan orang gaib, yaitu manusia yang digaibkan Allah.

Adanya orang gaib ini dalam Alquran secara tegas tidak disebutkan, namun secara tersirat terdapat pada Surat an-Nâs ayat 4-6 yang artinya: "Dari kejahatan (bisikan) setan yang biasa bersembunyi. Yang membisikan (kejahatan) ke dalam dada manusia. Dari golongan jin dan manusia". ${ }^{8}$ Dalam Alquran Surat 18 ayat 50, yang termasuk golongan jin itu adalah iblis/setan. Manusia bisa bersahabat atau bagampiran dengan jin ini serta bisa bekerja sama dan minta bantuan kepadanya. Namun bagi mereka meminta bantuan kepada jin tersebut tetap menambah dosa dan kesalahannya (Q.S. 72:6). Sedangkan dari golongan manusia yang membisikkan kejahatan ke dalam dada manusia itu, yang menurut hemat penulis adalah bisa berarti manusia yang jahat dan bisa berarti manusia yang digaibkan Allah. Sebab bisikan itu ke dada (Shudûr), bukan ke telinga manusia. Jadi secara tersirat orang gaib itu ada, dan diperkuat dari peristiwa dan pengalaman mereka yang telah merasa bagampiran dengan orang gaib tersebut. Para dukun pijat dan dukun beranak merasa sangat terbantu dalam persahabatan dengan orang gaib tersebut, sebab dapat menolong/membantu orang lain yang membutuhkan, dan ini merupakan suatu hal yang sifatnya keturunan. Bukan seperti bersahabat atau bagampiran dengan jin, yang sudah tentu telah diperoleh melalui usaha tapa, semedi atau balampah. Dan lain lagi persahabatan dengan malaikat, sebab keadaan yang terakhir ini merupakan hasil ibadah yang dilakukan secara terus menerus (istiqamah), sehingga malaikat turun membantunya (Q.S. 41:30-31).

${ }^{8}$ Yayasan Penyelenggara/Penterjemah/Pentafsir Alquran, Alquran dan Terjemahnya, (Jakarta: Departemen Agama, 1971), h. 1122. 
Bagampiran atau bersahabat dengan makhluk supernatural ini memang sangat meragukan, sebab yang dikira orang gaib tersebut, jangan-jangan dia adalah jin, karena jin bisa berubah bentuk, bisa seperti manusia, binatang dan lainnya. ${ }^{9}$ Justru itu agak susah menjelaskan secara ilmiah terjadinya proses bagampiran tersebut, tetapi biasanya mereka yang bagampiran lebih disebabkan oleh karena hubungan darah (geneologis) sehingga mereka yang digampiri dianggap sebagai "orang pilihan", yakni mereka yang secara kejiwaan memiliki bakat indigios (bakat untuk melihat atau berhubungan dengan hal-hal yang gaib, seperti paranormal). Bagampiran itu terjadi biasanya tanpa dikehendaki, bahkan kebanyakan kasus merupakan sesuatu yang tidak bisa ditolak oleh mereka yang digampiri.

Kepercayaan mengenai gampiran ini di kalangan sebagian masyarakat Banjar yang bertempat di Amuntai, tentunya terkait dengan kepercayaan mereka yang tampaknya sangat kental adanya unsur-unsur religio-magis. Dalam kasus ini mereka semuanya beragama Islam, namun sinkretisme mewarnai kehidupan mereka. Kepercayaan terhadap sesuatu yang gaib sangat melekat dengan alam budaya orang Banjar, baik disebabkan oleh pengaruh agama Islam maupun bersumber dari kepercayaan pra Islam. Dalam kaitan ini Roland Robertston menjelaskan bahwa apa yang disebut agama pada praktiknya di mana-mana tetap mengandung unsur magis tertentu. ${ }^{10}$ Hal yang sama juga diungkapkan oleh Fischer yang menyebutkan adanya "Osmose" (percampuran) antara religi kerakyatan dengan religi yang didatangkan. Religi kerakyatan adalah keberagamaan yang tumbuh secara natural dalam kehidupan masyarakat. Keberagamaan ini melekat bersama ajaran agama dalam kehidupan masyarakat yang kemudian menganut agama itu. Sinkretisme menggejala dalam banyak tradisi pada masyarakat kita, seperti memandikan ibu hamil, dengan dilengkapi berbagai peralatan seperti benang kuning, lilin menyala, cermin, sisir, air yasin dll. Sepertinya orang merasa ada jaminan keselamatan dalam melahirkan anak. Bermacam kepercayaan terhadap benda-benda yang ke luar saat melahirkan, yang disebut sahabat/saudara empat seperti tambuni makhluk

${ }^{9}$ Umar Sulaiman al-Asyqar, Alam Makbluk Supernatural, (Jakarta: CV. Firdaus 1992), h.

${ }^{10}$ Roland Robertston, Sociology of Religion, (Jakarta: CV. Rajawali, 1982), h. 416. 
gaibnya/rohnya adalah bernama Tambuniyah, Uri makhluk gaib/rohnya adalah bernama Uriyah, Tutuban makhluk gaibnya disebut Tubaniyah dan cairan/air makhluk gaibnya dikenal dengan nama Camariyah. Semua makhluk gaib itu disebut sahabat empat atau saudara empat yang sering menggampiri seseorang atau membantu dukun beranak. ${ }^{11}$

Kepercayaan masyarakat yang mengakui bahwa benda-benda yang mempunyai roh, itu disebut paham animisme. Roh itu memang bersemayam dalam benda itu dan bisa menegur/menyapa, membantu, mengganggu dsb. Roh itu memerlukan makanan dan minuman, sehingga diberilah sajen untuknya. Mereka yang tahu kehendak rorroh itu adalah dukun atau paranormal. Jadi untuk meminta pengaruh baiknya atau untuk menolak pengaruh jahatnya, diperlukan pengetahuan dan pengalaman dukun atau paranormal yang dapat berkomunikasi setelah membaca mantra atau menyediakan sajen tertentu. Para dukun sering juga menggunakan fetish, seperti pada paham dinamisme. ${ }^{12}$ Keadaan ini terlihat pada kasus I, yang menggunakan mandau sebagai alat pengobatan.

Malinowski mengakui bahwa antara agama dan kepercayaan masyarakat terhadap kekuatan gaib (magis) sulit dipisahkan, karena magis memberikan sumbangan terhadap moral manusia dengan memungkinkan manusia bertindak dalam situasi di mana mereka tidak dapat mengubah kondisi yang mengecewakan, dan dengan memberi manusia bantuan berupa harapan melalui perantara kekuatan adikodrati. $^{13}$

Apa yang di kemukakan oleh Malinowski memang beralasan, sebab kenyataan dalam kasus bagampiran (bersahabat makhluk gaib) banyak unsur-unsur magis dan dipercayai sebagai kekuatan yang diperoleh dari hasil berhubungan dengan makhluk gaib (supernatural) tersebut, sehingga mempunyai kemampuan tertentu, misalnya h. 13 .

${ }^{11}$ Nordiansyah, Sinkretisme, (Banjarmasin: Fakultas Ushuluddin IAIN Antasari 1982),

\footnotetext{
${ }^{12}$ M. Noerman, Aliran-aliran Kepercayaan dan Agama-agama Besar, (Jakarta: Mutiara 1975), h. 14 .

${ }^{13}$ O'dea Thomas F, Sociology of Religion, Terj. F.X. Sutanto, Jakarta: Rajawali Press, 1992), h. 14.
} 
mengobati atau menolong orang lain dengan cara-cara di luar ilmu kedokteran.

Dalam ajaran agama Islam dikenal kepercayaan terhadap sesuatu yang gaib ini, umumnya berkenaan dengan persoalan rukun iman, yang merupakan akidah muslim. Khusus mengenai makhluk gaib biasanya dihubungkan dengan malaikat, jin, iblis atau setan. Sementara dalam kepercayaan masyarakat Banjar yang berdiam di daerah Amuntai khususnya dan Kal-Sel pada umumnya, mempercayai di samping makhluk-makhluk gaib tersebut, juga dikenal kepercayaan terhadap adanya orang gaib/orang halus. Orang gaib/ orang halus adalah sejenis manusia yang digaibkan Allah, dengan kata lain manusia yang tinggal di alam gaib, yang bisa merasuk ke dalam tubuh manusia, sebagaimana jin.

Firyal Ulwah menyatakan Bangsa jin bisa merasuk ke dalam jiwa manusia, bahkan bisa kawin dengan umat manusia itu sendiri yaitu dengan cara mengubah wujudnya. Imam Ibnu Thaimiyah mengatakan bahwa jin dapat memasuki tubuh manusia karena syahwat dan nafsunya seperti halnya manusia yang dapat dipengaruhi manusia lain, dan kadang-kadang ada pula manusia yang kawin dengan jin dan beranak pinak. ${ }^{14}$ Keadaan ini sesuai dengan sabda Rasulullah saw. yang diriwayatkan Ibnu Abbas ra. Bahwa bagi suami janganlah menggauli isterinya sewaktu sedang haid karena iblis akan mencampurinya, dan ketika dia hamil maka yang lahir adalah mukhannats, yaitu anak-anak jin. Maka dari itulah Allah swt. melarang kita untuk mencampuri isteri yang sedang haid dan barang siapa yang melakukan itu dialah yang bertanggungjawab terhadap akibatnya, karena dapat menimbulkan penyakit baik pada suami/isteri. Lebih dari itu dia akan menerima akibatnya jika dari hubungan tersebut lahir mukhannats sebagai balasan yang setimpal. ${ }^{15}$ Tidak mustahil, ini yang disebut masyarakat dengan istilah Urang gaib.

${ }^{14}$ Firyal Ulwan, Misteri Alam jin, (Bandung: Pustaka Hidayah 1997), h. 18.

${ }^{15}$ M. Isa Daud, Dialog dengan Jin Muslim, (Bandung: Pustaka Hidayah, 1996), h. 119. 


\section{Penutup}

Suku Banjar khususnya yang ditinggal di daerah Hulu Sungai Utara (Amuntai) umumnya mereka mempercayai/meyakini adanya "orang gaib" selain daripada malaikat, jin, iblis/setan. Orang gaib ini dapat mengubah bentuknya seperti manusia atau hewan, dan bisa menempati benda tertentu. Kejadiannya berasal dari manusia yang digaibkan Allah, baik ketika masih dalam kandungan atau setelah lahir. Justru itu dia masih ada hubungan darah dengan manusia (seketurunan), dan masyarakat yakin manusia tidak akan melahirkan jin, sebab lain jenis, tapi manusia bisa saja melahirkan orang gaib (orang yang digaibkan Allah). orang gaib ini menggampiri orang-orang tertentu dari keluarganya, baik disadari atau tidak, dikehendaki atau terpaksa, bila sudah dipilihnya, maka susah untuk menghindarinya. orang gaib ini bisa membantu, menolong, mengganggu, dan bahkan bisa menyakiti. Berbagai keahlian dukun pijat, dukun beranak dan paranormal, merupakan hasil bantuan/pertolongan orang gaib tersebut, serta berbagai penyakit seperti kapubunan, kapingitan, kepidaraan, kesurupan dll. merupakan bentuk ganguannya. Agar orang gaib tersebut membantu dan tidak mengganggu/menyaki yang digampiri atau keluarganya, selalu diberi sajen yang berupa kue-kue, kopi manis dan pahit, serta tidak jarang dibuatkan kelambu kuning (ranjang kecil yang diberi tirai/kelambu warna kuning) untuk tempat orang gaib tersebut, yang diletakan pada tempat khusus. Hal ini sudah merupakan kebiasaan bagi masyarakat Banjar yang bagampiran. 


\section{DAFTAR PUSTAKA}

al-Asyqar, Umar Sulaiman, (1992). Alam Makbluk Supernatural, Jakarta: CV. Firdaus.

Bali, Wahid Abdus Salam, (1995). Kesurupan Jin dan Cara Pengobatannya Secara Islami, Jakarta: Robbani Press, Cet. ke-3.

Daud, Alfani, (1997). Islam dan Masyarakat Banjar, Jakarta: PT. RajaGrafindo.

Nordiansyah, (1982). Sinkretisme, Banjarmasin: Fakultas Ushuluddin IAIN Antasari.

Noeman, M., (1975). Aliran-aliran Kepercayaan dan Agama-agama Besar, Jakarta: Mutiara.

Robertston, Roland, (1982). Sociology of Relegion, terj. Jakarta: CV. Rajawali.

Thomas F, O'dea, (1992). Sociology of Religion, Terj. F. X. Sutanto, Jakarta: Rajawali Press.

Tim, (2004). Sejarah Banjar, Banjarmasin: Badan Penelitian dan Pengembangan daerah Propinsi Kalsel.

Ulwan, Firyal, (1997). Misteri Alam jin, Bandung: Pustaka Hidayah.

Yayasan Pelenggara Penterjemah/Penafsiran Alquran, (1971). Alquran dan Terjemahnya, Jakarta: Departemen Agama. 